Review

\title{
Functional and Healthy Features of Conventional and Non-Conventional Sourdoughs
}

\author{
Luciana De Vero*(D), Giovanna Iosca (D, Maria Gullo (D) and Andrea Pulvirenti *(D) \\ Unimore Microbial Culture Collection (UMCC), Department of Life Sciences, University of Modena and Reggio \\ Emilia, Via Amendola 2, 42122 Reggio Emilia, Italy; giovanna.iosca@unimore.it (G.I.); \\ maria.gullo@unimore.it (M.G.) \\ * Correspondence: luciana.devero@unimore.it (L.D.V.); andrea.pulvirenti@unimore.it (A.P.)
}

Citation: De Vero, L.; Iosca, G.; Gullo, M.; Pulvirenti, A. Functional and Healthy Features of Conventional and Non-Conventional Sourdoughs. Appl. Sci. 2021, 11, 3694. https:// doi.org/10.3390/app11083694

Academic Editor: Antonio Valero

Received: 17 March 2021

Accepted: 18 April 2021

Published: 20 April 2021

Publisher's Note: MDPI stays neutral with regard to jurisdictional claims in published maps and institutional affiliations.

Copyright: (c) 2021 by the authors. Licensee MDPI, Basel, Switzerland. This article is an open access article distributed under the terms and conditions of the Creative Commons Attribution (CC BY) license (https:// creativecommons.org/licenses/by/ $4.0 /)$.

\begin{abstract}
Sourdough is a composite ecosystem largely characterized by yeasts and lactic acid bacteria which are the main players in the fermentation process. The specific strains involved are influenced by several factors including the chemical and enzyme composition of the flour and the sourdough production technology. For many decades the scientific community has explored the microbiological, biochemical, technological and nutritional potential of sourdoughs. Traditionally, sourdoughs have been used to improve the organoleptic properties, texture, digestibility, palatability, and safety of bread and other kinds of baked products. Recently, novel sourdough-based biotechnological applications have been proposed to meet the demand of consumers for healthier and more natural food and offer new inputs for the food industry. Many researchers have focused on the beneficial effects of specific enzymatic activities or compounds, such as exopolysaccharides, with both technological and functional roles. Additionally, many studies have explored the ability of sourdough lactic acid bacteria to produce antifungal compounds for use as bio-preservatives. This review provides an overview of the fundamental features of sourdoughs and their exploitation to develop high value-added products with beneficial microorganisms and/or their metabolites, which can positively impact human health.
\end{abstract}

Keywords: sourdough; yeasts; lactic acid bacteria; bioactive compounds; exopolysaccharides; antifungal activity

\section{Introduction}

Sourdoughs, in all their different types produced worldwide, represent an awesome ecosystem which can offer several opportunities for conventional and non-conventional microbial exploitation to sustain the ecological and nutritional needs of new consumers [1].

Sourdough is a mixture of water and flour that is fermented by cultures of indigenous yeasts and lactic acid bacteria (LAB) [2-4]. In addition to these microorganisms, Proteobacteria may also be present, specially at the beginning of fermentation [5,6]. Among them, acetic acid bacteria (AAB), such as those belonging to Gluconobacter sp., Acetobacter sp., and Komagataeibacter sp., allow faster acidification of the dough and influence the volatile attributes of the final product [7-10]. The indigenous microflora of sourdough is the result of the microbial interaction among microorganisms coming from the flour, the bakery environment, and the vegetable matrices, such as fruits, must, or vinegar, which can be added to the original mixture to accelerate the start-up of fermentation [11].

For many decades the scientific community has explored the microbiological, biochemical, technological, and nutritional potential of sourdoughs and the overall literature, produced in the last 30 years, has been recently reviewed by Arora et al. [12]. What stands out are the novel sourdough-based biotechnological applications proposed, in the last decade, to meet the demand of consumers for healthier and more natural food $[13,14]$.

This review highlights the fundamental features of sourdoughs and their exploitation to develop high value-added products and offer new inputs for the food industry. 
In addition to the sourdough technology, this review deals with meaningful studies on the enzymatic activities that have positive effects on human health and the production of compounds with functional properties. Moreover, it reports the potential exploitation of sourdough lactic acid bacteria as bio-preservatives against fungal growth.

\section{Sourdough Technology}

Based on the technology applied for their production, three main types of sourdough can be distinguished: type I, which is the artisan bakery firm sourdough; type II, referring to industrial liquid sourdoughs; and type III, which indicates industrial dried sourdoughs $[15,16]$ (Figure 1).

Usually, mature type I sourdough contains a mixture of typical yeast and mesophilic LAB strains that characterize sourdough-based products [6]. The stability of the dough depends on the type of flour, the quality and nutritional value of the cereals, the temperature and humidity during processes, and the microbial composition of the inoculum [17,18].

The common yeast species are mainly Saccharomyces cerevisiae, Kazachstania humilis (formerly Candida humilis), Kazachstania exigua, Pichia kudriavzevii, and Torulaspora delbrueckii $[19,20]$. Moreover, almost $95 \%$ of the traditional sourdough population is dominated by heterofermentative LAB alone or in association with homofermentative lactobacilli [15,21]. Lactobacillus sanfranciscensis (currently Fructilactobacillus sanfranciscensis) was most frequently detected in association with yeasts belonging to Kazachstania species, predominantly K. humilis [22-24]. Other frequently representative LAB include Lactobacillus plantarum (currently Lactiplantibacillus plantarum), Lactobacillus brevis (currently Levilactobacillus brevis), Leuconostoc spp., and Weissella spp. [1,5,25,26].

To avoid any confusion for the Lactobacillus strains reported in previous studies with the former classification of the genus, the old name of the species will be maintained in the present review; the following link is suggested for the appropriate name conversion: http:/ / lactobacillus.ualberta.ca, accessed on 17 March 2021.

The type I sourdough is prepared according to the traditional method, conducted by daily refreshments, also called "back-slopping", which keeps it metabolically active. Accordingly, a selection of sourdough microbiota occurs, due to the back-slopping, which is repeated five to ten times [8,27]. These sourdoughs are typical of various traditional Italian sweet baked products, including those that are commercialized and consumed during holiday seasons, such as Panettone and Colomba $[3,18,28]$.

Type II and III sourdoughs (the latter is made by dehydrating the stabilized form of type II sourdough) were developed for industries with the aim of providing a more standardized process [6]. Both are made with selected cultures added at a ratio of 100:1 (LAB to yeasts) to obtain specific features of the baked products and inhibit the growth of unwanted microbiota [8].

The selection of microbial strains useful as starter cultures is fundamental for sourdough industries and relies on various metabolic traits that have both technological and functional interest $[29,30]$. In this context, qualified microbial culture collections, constitute a fundamental cornerstone for the investigation of sourdoughs' microbiota to select strains with desired features [31].

Among LAB, the selection of potential starters is generally made within the Lactobacillaceae and the most often used are acid-tolerant strains such as L. amylovorus, L. panis, L. pontis, and L. reuteri $[27,32,33]$.

Different non-lactobacillus strains have also been tested as suitable starters because of the positive effect of their compounds on the sourdough flavor, which can open new prospects in the sourdough industries. As reported by Montemurro et al. [34], Pediococcus pentosaceus OA1 and S3N3 and Leuconostoc citreum PRO17 were selected on the basis of optimal acidification and growth performance, as well as the intense proteolytic activity in whole wheat flour doughs.

Recently, AAB have also been considered useful starters for the production of desired metabolites [7]. Accordingly, Acetobacter pasteurianus IMDO 386B and Gluconobacter oxydans 
IMDO A845 strains were tested for type II sourdough production processes and the latter, in particular, had an attractive impact on the production of volatile organic compounds [7].
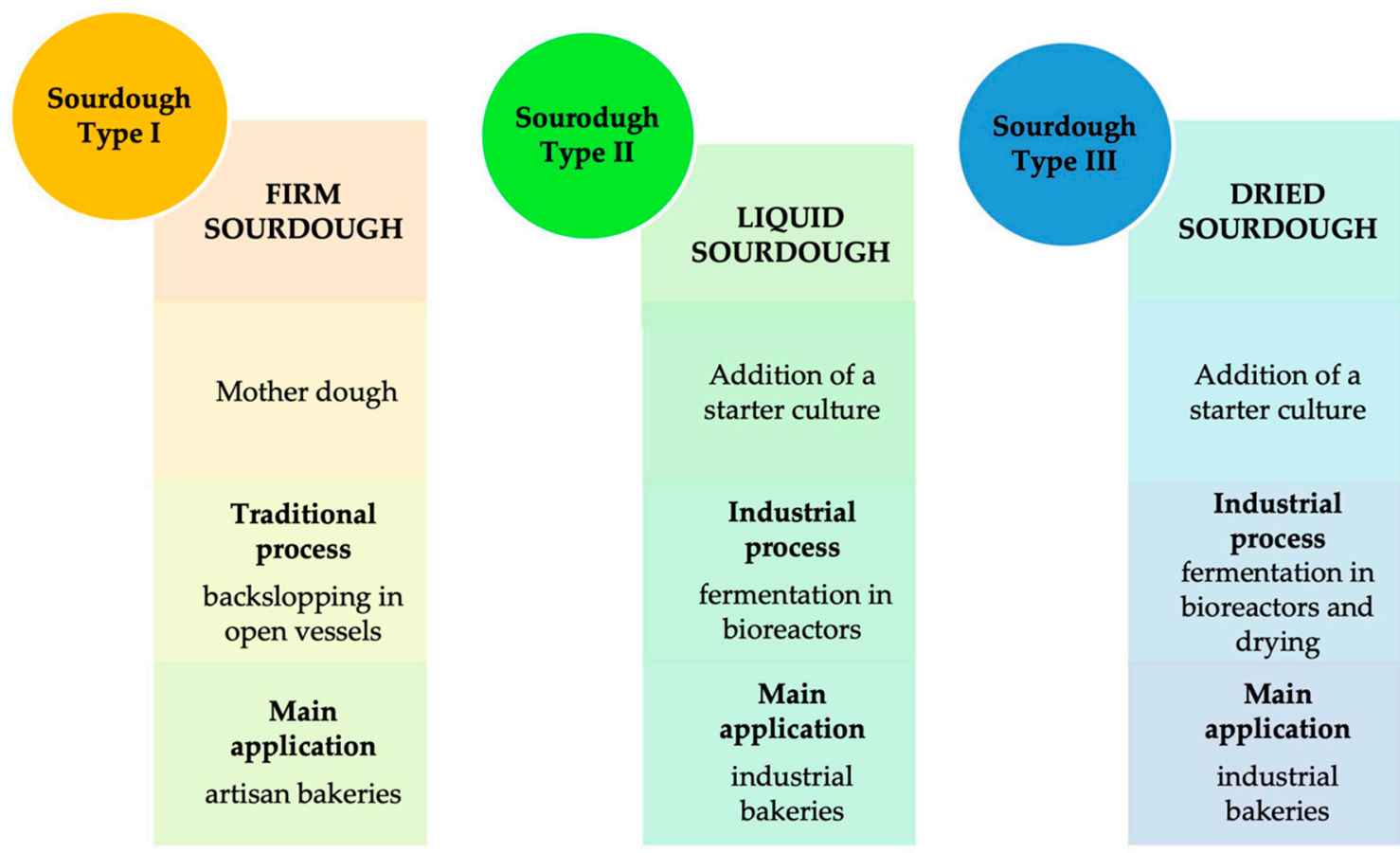

Figure 1. Schematic description of the three main types of sourdough.

\section{Nutritional and Functional Features of Sourdough}

Sourdough fermentation is certainly the most conventional and efficient tool for guaranteeing rheology, sensory, hygiene and shelf-life features [14]. Additionally, it has the potentiality to enhance the nutritional and functional features of wheat flours [35-38].

The positive effects provided by sourdough technology can be summarized as:

- preservation of food through acetic acid, lactic acid, alcoholic, and alkaline fermentations;

- food enrichment with compounds that originate either from biochemical reactions

(e.g., essential amino acids, proteins and essential fatty acids), or biosynthesis (e.g., vitamins);

- development of aromas, flavors and textures in food substrates;

- detoxification during food fermentation processing.

Moreover, it has been reported that sourdough fermentation can lower glycemic index, increase mineral bioavailability, reduce gluten content and reduce starch digestibility, mainly through the organic acids production and other complementary mechanisms $[12,39]$. The main outcomes of sourdough fermentation are shown in Figure 2.

In recent years the development of high-quality gluten-free (GF) products has become an important socio-economic issue and a new approach in this framework is represented by the application of sourdough fermentation [40].

Common products for celiacs available on the market are often characterized by poor palatability and lack of minerals and fibers [41]. Moreover, they usually have a low amount of health promoting nutrients, such as B vitamins groups, which are essential in the human diet; for instance, folate (B11) is involved in fundamental metabolic reaction, biosynthesis of nucleotides, building blocks of DNA and RNA and prevent neural tube defects in newborns [40]. Consequently, fermentation with LAB and yeasts can be considered an effective methodology in food production suitable for the development of new kinds of GF products with nutraceutical and health-promoting features [42]. Applying microbial selected cultures to suitable raw materials, the fermentation process can be modulated, also 
enhancing the content of bioactive metabolites and other compounds, such as glutathione, which exert an antioxidant activity [22,43-45].

Moreover, the sourdough fermentation can be useful in preserving some good sensory characteristics, such as products' structure and/or softness maintenance during storage, which are usually compromised by the lack of gluten $[46,47]$. Therefore, the selection of specific sourdough cultures has been considered as a new tool for GF food processing [14,48,49].

Various ecological studies have provided useful information on the presence of competitive LAB and yeasts strains, which can be used as candidates for starter development [50]. In rice, maize, teff, and amaranth sourdough, for instance, is frequently used to isolate microorganisms such as: L. fermentum, L. plantarum, and L. paralimentarius [51]. Above them, strains of L. helveticus, L. pontis, and S. cerevisiae are most competitive in different kind of cereals, pseudo-cereals, and cassava sourdoughs [10,52]. Positive cooking performance, obtained with the use of sourdough in GF products, in terms of definite volume, flavor, texture and mouthfeel encourages further studies and the development of an industrial production [40].

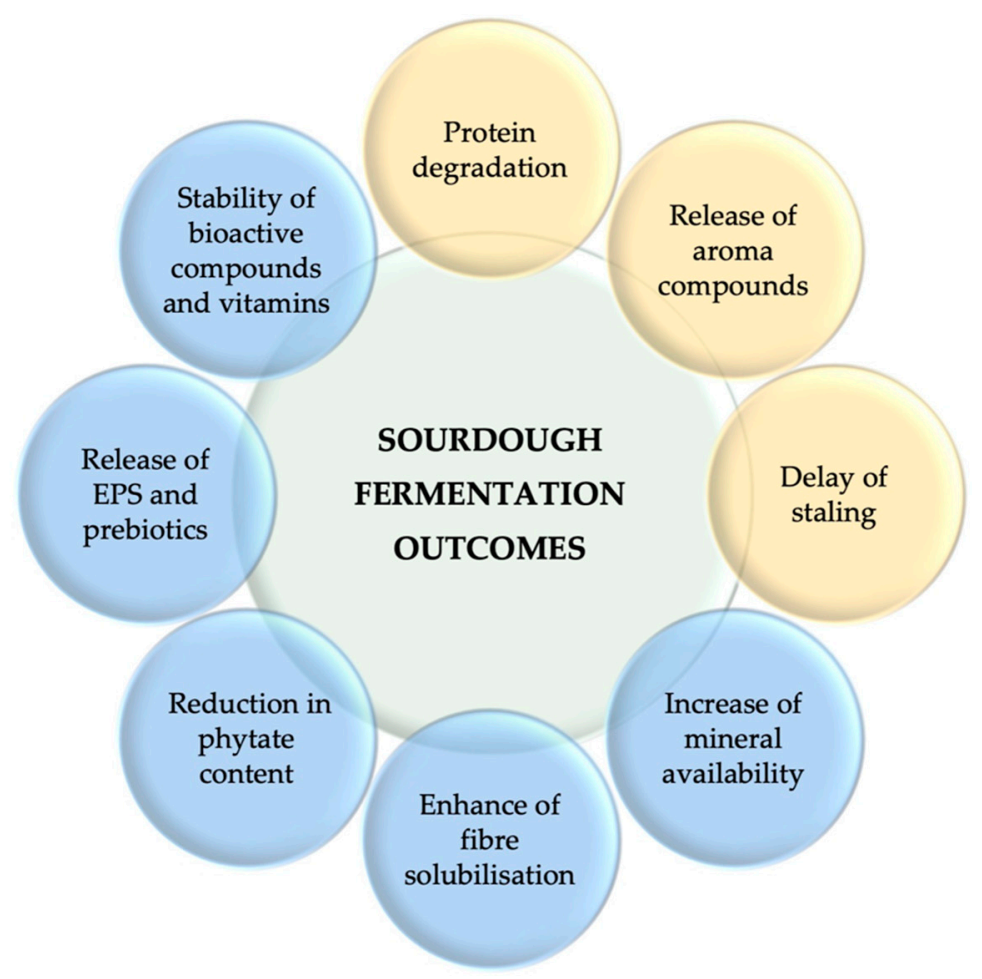

Figure 2. Main technological effects of sourdough on rheology, flavor and shelf life (in yellow), and main health-promoting features (in light blue).

In particular, the flavor profile of the product can be greatly affected by the use of sourdough, depending on type of starter cultures, fermentation conditions, baking conditions and raw material. Recently, researchers have proposed the use of sourdoughfermented ingredients to reach new sensorial profile and enhance nutritional value in pasta [13]. The use of sourdough for pasta fortification has been explored under several aspects and has also been applied with success to mixed flour composed by pseudo-cereals and legumes, allowing an increasing of $\gamma$-aminobutyric acid (GABA) levels [53]. GABA is a non-protein amino acid with several physiological functions, such as induction of hypotension and prevention of diabetes as well as diuretic and tranquilizer effects [54,55]. A systematic review on its production from LAB has been recently reported by Cui et al. [56]. The use of non-conventional flours to obtain food products characterized by peculiar flavor, abundance of proteins with high nutritional value, dietary fibers, polyphenols, 
and minerals, represent an attractive feature to be explored by food industries for new applications of sourdough microbiota [26,42].

\subsection{Enzymatic Activities with Beneficial Effects on Human Health}

It is known that cereal grains are significant sources of minerals such as magnesium, potassium, iron and zinc. However, they also contain phytic acid or myo-inositol hexakiphosphate (IP6) (1-4\% of dry weight) [57,58]. This compound is an anti-nutritional factor for humans and animals, in fact, the central hexaphosphate ring is highly charged due to six anionic groups and acts as a chelator of dietary minerals reducing their bioavailability $[59,60]$. Sourdough fermentation, owing to the $\mathrm{pH}$ reduction, provides suitable conditions for cereal endogenous phytase activities [36,61]. The phytases that take part in the process are also exogenous and they are produced by a large number of microorganisms among which are sourdough yeasts and LAB. Their activity reduces to less than a half the phytate content of whole wheat bread and allows to increase bioavailability of minerals, free amino acids, and proteins. A recent screening on $152 \mathrm{LAB}$, isolated from cereal-based substrates, revealed a widespread capacity of the isolates $(95 \%)$ for degrading phytic acid. Among the isolates, strains L. brevis LD65 and L. plantarum PB241, showed the highest phytase activity; on the contrary, Weissella confusa strains showed low or no phytase activity [62].

Allergies, intolerances, and sensitive individuals are also positively influenced by the LAB present in the sourdough, as they can show specific enzymatic activities toward gluten proteins. The proteolytic activity carried out by endogenous and exogenous proteases during the fermentation process with sourdough seems to lead to a complete hydrolysis of gluten, meeting the needs of individuals affected by celiac disease [32].

\subsection{Effects of Organic Acids}

Most of the valuable properties attributed to sourdough are due to the acidification activity, due to $\mathrm{LAB}$ and $\mathrm{AAB}$. In fact, during fermentation, several organic acids, e.g., lactic, acetic, citric, pyruvic and succinic acid are produced. Among them, lactic and acetic acid are the most important as they can greatly affect the aroma profile and rheological properties of sourdoughs [58]. Their production depends upon several factor including flour type, starter used, metabolic activity, technological performance, and acidification properties of the wheat sourdoughs [63]. Organic acids produced during sourdough fermentation can have preservative and antimicrobial effects, improving storability and safety [64], as well as have positive health effects. For instance, acetic acid, propionic and lactic acid have the capacity of lowering the insulin response [65]. The mechanisms of these acids seem to vary; lactic acid acts to lower the rate of starch digestion in bread while propionic and acetic acids seem to extend the gastric emptying rate [66].

As suggested by the work of Östman et al. [67], lactic acid, in particular, is designed to lower blood sugar and promote an interaction between starch and gluten favoring the reduction of starch bioavailability.

\section{Exopolysaccharides}

Exopolysaccharides (EPS) are biopolymers of high molecular weight produced by several microorganisms, such as LAB, AAB and microalgae [68-70].

Based on the chemical composition and biosynthesis mechanisms, microbial EPS are classified into two distinct groups: (1) homopolysaccharides (HoPS), such as glucans and fructans, (2) heteropolysaccharides (HePS), e.g., gellan and xanthan [71]. Among the HoPS, dextran, levan, and cellulose are mostl important in the food industry for their significant features [71,72]. In particular, EPS-producing LAB are attractive for application in bakery products thanks to their ability as viscosifiers, texturizers, emulsifiers, and syneresis-lowering agents [62,70]. In addition to polysaccharides naturally occurring in cereal grains flour and dough, microbial EPS from sucrose can be produced in sourdough through the activity of glycosyltransferases [73]. It has been reported that fructan from $L$. 
sanfransiscensis can positively affect the dough rheology and bread texture more than the external addition of the same polysaccharides [74]. Furthermore, it has been shown that dextran produced in situ can improve texture and cover unpleasant flavors of wholegrain bread suggesting microbial EPS as a possible substitute of sweeteners [75].

Sourdough technology using EPS-producing LAB strains seem to be a valid solution to improve GF baked products [70]. For instance, microbial EPS can replace hydrocolloids, which are fundamental components in GF products to get acceptable quality levels in terms of texture, volume, and shelf life [76].

Other evidence has been recently reported by Franco et al. [77], who described EPS, produced by Pediococcus, Leuconostoc, and Weisella strains in quinoa sourdough, able to improve the organoleptic and rheological attributes in GF-free doughs. Consequently, the development of EPS-producing starter cultures for different types of flour sourdoughs has been receiving a growing-interest in the last years, also due to the potential health benefits associated with EPS themselves as prebiotics, which can be exploited to make added-value functional products [78]

\section{Bioactive Compounds}

Cereals contain different phytochemicals, such as phenolic acids, phytosterols, alkylresorcinols, tocols, lignans, and folate [79]. Among other processing conditions, e.g., milling and malting, the sourdough fermentation is the one that most affects the levels and bioavailability of phytochemicals and increases the level of extractable phenolic compounds $[14,80]$. Furthermore, bioactive compounds are synthesized during fermentation, while other components involved in grain-related digestion problems or pathologies, such as gluten sensitivity or gastrointestinal syndromes, are reduced [81].

As reported by Katina et al. [82], folate and other free phenolic acids increased up to seven and ten times in germinated rye during sourdough fermentation. Moreover, comparing the capability of different yeasts and LAB to affect the folate content in a rye sourdough, it was demonstrated that the synthesis of folate by bacteria was minimal, while the yeasts were able to increase its content over three-fold in the best case [83].

Regarding the vitamin E, tocopherol and tocotrienol, a reduction during the sourdough preparation and dough making has been reported, probably due to the sensitivity of the compounds to the air [14].

Several authors have stated LAB as the microbes most suitable in bioactive peptides enrichment [55,84]. According to Rizzello et al. [49,55], selected sourdough lactobacilli with specific proteinase and peptidase activities toward cereal proteins, were effectively used for releasing Angiotensin I-Converting Enzyme (ACE)-inhibitory peptides during a long-time sourdough fermentation. These peptides are of great interest for functional foods as they may be used for avoiding hypertension and for other therapeutic purposes [55]. Another study showed that sourdough LAB can increase the concentration of lunasin, a cancer-preventing peptide, during fermentation of various flours, including those of wheat, barley, amaranth, soybean, or rye [85]. Specifically, L. curvatus SAL33 and L. brevis AM7 strains used as sourdough starters were able to synthesize this compound, increasing its concentration up to 2-4 times during fermentation.

\section{Antifungal Compounds}

One of the big issues in the bakery product industries are moulds - the primary cause of spoilage, off-flavors and potentially producing harmful secondary metabolites commonly called mycotoxins. Aflatoxins are the most common hazardous mycotoxins, causing both chronic and acute toxicity to humans and cattle. Usually, chemical preservatives are successfully used against fungal growth, however, the exploitation of sourdough LAB, as bio-preservatives, has gained great interest among researchers and industries driven by the growing demand for clean label products in which chemically derived ingredients are replaced by natural alternatives [86]. 
Generally, LAB can be considered protective microorganisms not only for their production of lactate and acetate, which act as effective preservatives, but also for releasing other active compounds during fermentation. Indeed, a synergistic effect between $\mathrm{pH}$ and antifungal metabolites seems to be responsible of the LAB protective activity $[87,88]$. The majority of antifungal substances produced from LAB include organic acids, hydrogen peroxide, reuterin, proteinaceous and phenolic compounds, hydroxyl fatty acids, and other low-molecular-weight compounds [89,90].

Several studies have investigated the ability of sourdough LAB to prevent moulding events on leavened goods; some examples referred to specific strains are reported in Table 1. A comprehensive review on the ability of LAB to serve as antifungal and anti-mycotoxigenic agents have been recently provided by Sadiq et al. [86].

Table 1. Some lactic acid bacteria strains from sourdoughs tested for their antifungal activity.

\begin{tabular}{|c|c|c|c|}
\hline LAB Strains & Compounds with Antifungal Activity & Fungal Target Tested & Reference \\
\hline L. sanfrancisencis CB1 & $\begin{array}{l}\text { Acetic, caproic, formic, propionic, butyric } \\
\text { and n-valeric acids }\end{array}$ & Fusarium graminearum 623 & [91] \\
\hline L. plantarum $21 \mathrm{~B}$ & $\begin{array}{c}\text { Phenyllactic acid and } \\
\text { 4-hydroxyphenyllactic acid }\end{array}$ & Aspergillus niger FTDC 3227 & [92] \\
\hline $\begin{array}{l}\text { L. plantarum CRL } 778 \\
\text { L. reuteri CRL } 1100 \\
\text { L. brevis CRL } 772 \\
\text { L. brevis CRL } 796\end{array}$ & Lactic, acetic, and phenyllactic acids & $\begin{array}{c}\text { Penicillium sp. } \\
\text { Aspergillus niger } \\
\text { Fusarium graminearum }\end{array}$ & [93] \\
\hline $\begin{array}{l}\text { L. buchneri FUA } 3525 \\
\text { L. diolovorans DSM } 14421\end{array}$ & Propionate and acetate & $\begin{array}{l}\text { Aspergillum clavatus } \\
\text { Cladisporium spp. } \\
\text { Mortierella spp. } \\
\text { Penicillium Roquefort }\end{array}$ & [94] \\
\hline $\begin{array}{c}\text { L. rossiae } \mathrm{LD} 108, \\
\text { L. paralimentarius } \mathrm{PB} 127\end{array}$ & $\begin{array}{l}\text { Lactic acid, acetic acid, phenyllactic acid } \\
\text { and diacetyl }\end{array}$ & Aspergillum japonicus & [95] \\
\hline L. amylovorus DSM 19280 & $\begin{array}{c}\text { Lactic acid, acetic acid, } \\
\text { 3-phenylpropanoic acid, p-coumaric, } \\
\text { (E)-2-methylcinnamic acid, 3-phenyllactic } \\
\text { acid and cyclic dipetides }\end{array}$ & $\begin{array}{c}\text { Fusarium culmorum FST } 4.05 \\
\text { Aspergillus niger FST4.21 } \\
\text { Penicillium expansum FST } 4.22 \\
\text { Penicillium roqueforti FST } 4.11\end{array}$ & {$[96,97]$} \\
\hline L. paracasei subsp. tolerans L17 & $\begin{array}{l}\text { Cell-wall binding and enzyme-mediated } \\
\text { degradation }\end{array}$ & $\begin{array}{l}\text { Fusarium proliferatum M } 5991 \\
\text { Fusarium proliferatum M } 5689 \\
\text { Fusarium graminearum R } 4053\end{array}$ & {$[98,99]$} \\
\hline
\end{tabular}

\section{Sourdough Effectiveness on Rheology, Shelf-Life and Safety}

The impact of sourdough on properties and rheological behavior of dough has been widely investigated. Generally, changes may be attributed to several intrinsically related factors, including variations in the rate or amount of acid produced [100].

For instance, a low proteolytic degradation of wheat proteins affects the physical properties of gluten and, thus, influences the firmness and staling of the final baked product [101]. The specific proteolytic activity of sourdough microorganisms also has a great impact [102]. As proved by Clarke et al. [103], the use of sourdough, prepared either from a single strain or a mixed strain starter culture, significantly influenced the rheological properties of wheat flour dough; sourdough prepared with starter cultures increased the softening level of the dough.

Regarding gas production in sourdoughs, Hammes and Gänzle [27] proved that the contribution of yeasts and $\mathrm{LAB}$ changes according to the type of starter and the dough technology. This aspect is particularly important in the GF products where the lack of the viscoelastic gluten system is responsible for low expansion and gas retention during leavening [104]. The efficiency of the addition of sourdough on GF bread quality was demonstrated in various formulations made of a different kind of flour by Picozzi 
et al. [105], which used a Type I GF-sourdough with a stable association between L. sanfranciscensis and C. humilis. The positive effects of sourdough on rheology and texture, in terms of volume and softness, led to an extended shelf-life of the baked products. This aspect is certainly of great interest for the bakery industry which has recently reevaluated the traditional sourdough fermentation to contrast the short shelf-life of baked products, like bread, mainly caused by spoilage microorganisms.

In fact, sourdough can act as a natural preservative able to replace the use of chemical preservatives. Above the antifungal activity described in the previous section, antibacterial activity has been also scientifically proven [106]. Bread quality and safety can be affected by spore-forming bacteria, such as Bacillus subtilis, which mainly occur on the outer parts of grains, and consequently can contaminate also the other ingredients and/or bakery environment $[107,108]$. The antibacterial effect of sourdough is generally attributed to the synergistic activity of several compounds produced by yeasts and LAB, which includes the synthesis of organic acids, EPS, antimicrobial compounds, bioactive peptides as well as the conversion of phenolic compounds and lipids [106,109,110].

Therefore, sourdough technology combined with the use of high-quality flours represent a tool for improving both organoleptic and healthy features of the baked goods. Optimized sourdoughs obtained with non-conventional flours are the new input for food companies which want to satisfy the needs of consumers affected by allergies and food intolerance.

Legumes and pseudocereals, such as amaranth and quinoa, which have very different chemical composition and technological properties compared to wheat, can be a valid alternative useful for the development of new food products included in different kinds of bread, pasta, or snacks [13]. Regarding the allergies issue, the European Regulation No. $1169 / 2011$ have been adopted with the aim to improve the labeling of foods with the clear indication of ingredients and nutritional values. Accurate food labeling can, in fact, allow consumers suffering from allergies or intolerances of knowing the specific ingredients present in food products and help them to make healthier choices [111].

\section{Conclusions}

Sourdough fermentation has emerged in human history and since then, it has been empirically used for the improvement of the organoleptic properties, texture, digestibility, palatability, and safety of different food matrices. Nowadays, sourdough fermentation is widely employed to enrich food with beneficial microorganisms and/or their metabolites, which positively impact human health. This result can be achieved either through the exploitation of the wild microbiota naturally associated to raw materials or as the result of the inoculation of selected starters.

The wide and successful use of sourdough, maintained over time for its peculiar and unique features, confirms this ancient biotechnology as an effective answer to the modern world demand for natural, healthy, and eco-friendly food.

Author Contributions: L.D.V., conceptualization, writing—review and editing; G.I., writing partially the original draft and editing; M.G., writing, review and editing; A.P., supervision and review. All authors have read and agreed to the published version of the manuscript.

Funding: This work was supported by the EU Project "Implementation and Sustainability of Microbial Resource Research Infrastructure for the 21st Century" (IS_MIRRI21, Grant Agreement Number 871129).

Institutional Review Board Statement: Not applicable.

Informed Consent Statement: Not applicable.

Acknowledgments: The JRU MIRRI-IT (http:/ / www.mirri-it.it/) is greatly acknowledged for scientific support.

Conflicts of Interest: The authors declare no conflict of interest. 


\section{References}

1. De Vuyst, L.; Van Kerrebroeck, S.; Harth, H.; Huys, G.; Daniel, H.M.; Weckx, S. Microbial ecology of sourdough fermentations: Diverse or uniform? Food Microbiol. 2014, 37, 11-29. [CrossRef]

2. Gobbetti, M. The sourdough microflora: Interactions of lactic acid bacteria and yeasts. Trends Food Sci. Technol. 1998, 9, 267-274. [CrossRef]

3. Garofalo, C.; Silvestri, G.; Aquilanti, L.; Clementi, F. PCR-DGGE analysis of lactic acid bacteria and yeast dynamics during the production processes of three varieties of Panettone. J. Appl. Microbiol. 2008, 105, 243-254. [CrossRef]

4. Pulvirenti, A.; Solieri, L.; Gullo, M.; De Vero, L.; Giudici, P. Occurence and dominance of yeast species in sourdough. Lett. Appl. Microbiol. 2004, 38, 113-117. [CrossRef]

5. Celano, G.; De Angelis, M.; Minervini, F.; Gobbetti, M. Different flour microbial communities drive to sourdoughs characterized by diverse bacterial strains and free amino acid profiles. Front. Microbiol. 2016, 7, 1770. [CrossRef] [PubMed]

6. De Vuyst, L.; Van Kerrebroeck, S.; Leroy, F. Microbial ecology and process technology of sourdough fermentation. Adv. Appl. Microbiol. 2017, 100, 49-160. [PubMed]

7. Comasio, A.; Van Kerrebroeck, S.; Harth, H.; Verté, F.; De Vuyst, L. Potential of bacteria from alternative fermented foods as starter cultures for the production of wheat sourdoughs. Microorganisms 2020, 8, 1534. [CrossRef] [PubMed]

8. Siepmann, F.B.; Ripari, V.; Waszczynskyj, N.; Spier, M.R. Overview of Sourdough Technology: From Production to Marketing. Food Bioprocess Technol. 2018, 11, 242-270. [CrossRef]

9. Chaves-Lopez, C.; Serio, A.; Delgado-Ospina, J.; Rossi, C.; Grande-Tovar, C.D.; Paparella, A. Exploring the bacterial microbiota of colombian fermented maize dough "Masa agria" (Maiz añejo). Front. Microbiol. 2016, 7, 1168. [CrossRef] [PubMed]

10. Vogelmann, S.A.; Seitter, M.; Singer, U.; Brandt, M.J.; Hertel, C. Adaptability of lactic acid bacteria and yeasts to sourdoughs prepared from cereals, pseudocereals and cassava and use of competitive strains as starters. Int. J. Food Microbiol. 2009, 130, 205-212. [CrossRef]

11. Catzeddu, P.; Mura, E.; Parente, E.; Sanna, M.; Farris, G.A. Molecular characterization of lactic acid bacteria from sourdough breads produced in Sardinia (Italy) and multivariate statistical analyses of results. Syst. Appl. Microbiol. 2006, 29, 138-144. [CrossRef] [PubMed]

12. Arora, K.; Ameur, H.; Polo, A.; Di Cagno, R.; Rizzello, C.G.; Gobbetti, M. Thirty years of knowledge on sourdough fermentation: A systematic review. Trends Food Sci. Technol. 2021, 108, 71-83. [CrossRef]

13. Montemurro, M.; Coda, R.; Rizzello, C.G. Recent advances in the use of sourdough biotechnology in pasta making. Foods 2019, 8 , 129. [CrossRef] [PubMed]

14. Gobbetti, M.; De Angelis, M.; Di Cagno, R.; Calasso, M.; Archetti, G.; Rizzello, C.G. Novel insights on the functional/nutritional features of the sourdough fermentation. Int. J. Food Microbiol. 2019, 302, 103-113. [CrossRef]

15. De Vuyst, L.; Neysens, P. The sourdough microflora: Biodiversity and metabolic interactions. Trends Food Sci. Technol. 2005, 16, 43-56. [CrossRef]

16. Chavan, R.S.; Chavan, S.R. Sourdough Technology-A Traditional Way for Wholesome Foods: A Review. Compr. Rev. Food Sci. Food Saf. 2011, 10, 169-182. [CrossRef]

17. Gullo, M.; Romano, A.D.; Pulvirenti, A.; Giudici, P. Candida humilis-Dominant species in sourdoughs for the production of durum wheat bran flour bread. Int. J. Food Microbiol. 2003, 80, 55-59. [CrossRef]

18. Foschino, R.; Gallina, S.; Andrighetto, C.; Rossetti, L.; Galli, A. Comparison of cultural methods for the identification and molecular investigation of yeasts from sourdoughs for Italian sweet baked products. FEMS Yeast Res. 2004, 4, 609-618. [CrossRef]

19. Pulvirenti, A.; Caggia, C.; Restuccia, C.; Gullo, M.; Giudici, P. DNA fingerprinting methods used for identification of yeasts isolated from Sicilian sourdoughs. Ann. Microbiol. 2001, 51, 107-120.

20. Carbonetto, B.; Nidelet, T.; Guezenec, S.; Perez, M.; Segond, D.; Sicard, D. Interactions between Kazachstania humilis yeast species and lactic acid bacteria in Sourdough. Microorganisms 2020, 8, 240. [CrossRef]

21. Hammes, W.P.; Vogel, R.F. The genus Lactobacillus. In The Genera of Lactic Acid Bacteria, 1st ed.; Springer: Boston, MA, USA, 1995; pp. $19-54$.

22. Xu, D.; Zhang, Y.; Tang, K.; Hu, Y.; Xu, X.; Gänzle, M.G. Effect of Mixed Cultures of Yeast and Lactobacilli on the Quality of Wheat Sourdough Bread. Front. Microbiol. 2019, 10, 2113. [CrossRef]

23. De Vuyst, L.; Harth, H.; Van Kerrebroeck, S.; Leroy, F. Yeast diversity of sourdoughs and associated metabolic properties and functionalities. Int. J. Food Microbiol. 2016, 239, 26-34. [CrossRef]

24. Foschino, R.; Picozzi, C.; Galli, A. Comparative study of nine Lactobacillus fermentum bacteriophages. J. Appl. Microbiol. 2001, 91, 394-403. [CrossRef] [PubMed]

25. Zheng, J.; Wittouck, S.; Salvetti, E.; Franz, C.M.A.P.; Harris, H.M.B.; Mattarelli, P.; O'toole, P.W.; Pot, B.; Vandamme, P.; Walter, J.; et al. A taxonomic note on the genus Lactobacillus: Description of 23 novel genera, emended description of the genus Lactobacillus beijerinck 1901, and union of Lactobacillaceae and Leuconostocaceae. Int. J. Syst. Evol. Microbiol. 2020, 70, 2782-2858. [CrossRef] [PubMed]

26. Gänzle, M.G.; Zheng, J. Lifestyles of sourdough lactobacilli-Do they matter for microbial ecology and bread quality? Int. J. Food Microbiol. 2019, 302, 15-23. [CrossRef]

27. Hammes, W.P.; Gänzle, M.G. Sourdough breads and related products. In Microbiology of Fermented Foods; Wood, B.J.B., Ed.; Springer: Boston, MA, USA, 1998; pp. 199-216. 
28. Vernocchi, P.; Valmorri, S.; Gatto, V.; Torriani, S.; Gianotti, A.; Suzzi, G.; Guerzoni, M.E.; Gardini, F. A survey on yeast microbiota associated with an Italian traditional sweet-leavened baked good fermentation. Food Res. Int. 2004, 37, 469-476. [CrossRef]

29. Pulvirenti, A.; Rainieri, S.; Boveri, S.; Giudici, P. Optimizing the selection process of yeast starter cultures by preselecting strains dominating spontaneous fermentations. Can. J. Microbiol. 2009, 55, 326-332. [CrossRef]

30. Corsetti, A. Handbook on Sourdough Biotechnology, 1st ed.; Springer: Boston, MA, USA, 2013; pp. 1-298.

31. De Vero, L.; Boniotti, M.B.; Budroni, M.; Buzzini, P.; Cassanelli, S.; Comunian, R.; Gullo, M.; Logrieco, A.F.; Mannazzu, I.; Musumeci, R.; et al. Preservation, characterization and exploitation of microbial biodiversity: The perspective of the Italian network of culture collections. Microorganisms 2019, 7, 685. [CrossRef]

32. Clarke, C.I.; Arendt, E.K. A Review of the Application of Sourdough Technology to Wheat Breads. Adv. Food Nutr. Res. 2005, 49, 137-161. [PubMed]

33. Huys, G.; Daniel, H.M.; De Vuyst, L. Taxonomy and biodiversity of sourdough yeasts and lactic acid bacteria. In Handbook on Sourdough Biotechnology; Gobbetti, M., Gänzle, M., Eds.; Springer: Boston, MA, USA, 2013.

34. Montemurro, M.; Celano, G.; De Angelis, M.; Gobbetti, M.; Rizzello, C.G.; Pontonio, E. Selection of non-Lactobacillus strains to be used as starters for sourdough fermentation. Food Microbiol. 2020, 90, 103-491. [CrossRef]

35. Coda, R.; Di Cagno, R.; Gobbetti, M.; Rizzello, C.G. Sourdough lactic acid bacteria: Exploration of non-wheat cereal-based fermentation. Food Microbiol. 2014, 37, 51-58. [CrossRef] [PubMed]

36. Gobbetti, M.; Rizzello, C.G.; Di Cagno, R.; De Angelis, M. How the sourdough may affect the functional features of leavened baked goods. Food Microbiol. 2014, 37, 30-40. [CrossRef] [PubMed]

37. Facco Stefanello, R.; Nabeshima, E.H.; de Oliveira Garcia, A.; Heck, R.T.; Valle Garcia, M.; Martins Fries, L.L.; Venturini Copetti, M. Stability, sensory attributes and acceptance of panettones elaborated with Lactobacillus fermentum IAL 4541 and Wickerhamomyces anomallus IAL 4533. Food Res. Int. 2019, 116, 973-984. [CrossRef]

38. Çakır, E.; Arıcı, M.; Durak, M.Z. Biodiversity and techno-functional properties of lactic acid bacteria in fermented hull-less barley sourdough. J. Biosci. Bioeng. 2020, 130, 450-456. [CrossRef]

39. Siepmann, F.B.; Sousa de Almeida, B.; Waszczynskyj, N.; Spier, M.R. Influence of temperature and of starter culture on biochemical characteristics and the aromatic compounds evolution on type II sourdough and wheat bread. LWT 2019, 108, 199-206. [CrossRef]

40. Zannini, E.; Pontonio, E.; Waters, D.M.; Arendt, E.K. Applications of microbial fermentations for production of gluten-free products and perspectives. Appl. Microbiol. Biotechnol. 2012, 93, 473-485. [CrossRef]

41. Zoumpopoulou, G.; Tsakalidou, E. Gluten-free products. In The Role of Alternative and Innovative Food Ingredients and Products in Consumer Wellness; Galanakis, C., Ed.; Academic Press: Cambridge, MA, USA, 2019; pp. $213-237$.

42. Rizzello, C.G.; Coda, R.; Gobbetti, M. Use of sourdough fermentation and non wheat flours for enhancing nutritional and healthy properties of wheat-based foods. In Fermented Foods in Health and Disease Prevention; Frías, J., Martínez-Villaluenga, C., Peñas, E., Eds.; Academic Press: Cambridge, MA, USA, 2016; pp. 433-452.

43. Pophaly, S.D.S.D.; Singh, R.; Pophaly, S.D.S.D.; Kaushik, J.K.; Tomar, S.K. Current status and emerging role of glutathione in food grade lactic acid bacteria. Microb. Cell Fact. 2012, 11, 1-14. [CrossRef]

44. De Vero, L.; Bonciani, T.; Verspohl, A.; Mezzetti, F.; Giudici, P. High-glutathione producing yeasts obtained by genetic improvement strategies: A focus on adaptive evolution approaches for novel wine strains. AIMS Microbiol. 2017, 3, 155-170. [CrossRef]

45. Bonciani, T.; De Vero, L.; Mezzetti, F.; Fay, J.C.; Giudici, P. A multi-phase approach to select new wine yeast strains with enhanced fermentative fitness and glutathione production. Appl. Microbiol. Biotechnol. 2018, 102, 2269-2278. [CrossRef]

46. Moore, M.M.; Heinbockel, M.; Dockery, P.; Ulmer, H.M.; Arendt, E.K. Network formation in gluten-free bread with application of transglutaminase. Cereal Chem. 2006, 83, 28-36. [CrossRef]

47. Moore, M.M.; Juga, B.; Schober, T.J.; Arendt, E.K. Effect of lactic acid bacteria on properties of gluten-free sourdoughs, batters, and quality and ultrastructure of gluten-free bread. Cereal Chem. 2007, 84, 357-364. [CrossRef]

48. Di Cagno, R.; Rizzello, C.G.; De Angelis, M.; Cassone, A.; Giuliani, G.; Benedusi, A.; Limitone, A.; Surico, R.F.; Gobbetti, M. Use of selected sourdough strains of Lactobacillus for removing gluten and enhancing the nutritional properties of gluten-free bread. J. Food Prot. 2008, 71, 1491-1495. [CrossRef] [PubMed]

49. Rizzello, C.G.; De Angelis, M.; Di Cagno, R.; Camarca, A.; Silano, M.; Losito, I.; De Vincenzi, M.; De Bari, M.D.; Palmisano, F.; Maurano, F.; et al. Highly efficient gluten degradation by lactobacilli and fungal proteases during food processing: New perspectives for celiac disease. Appl. Environ. Microbiol. 2007, 73, 4499-4507. [CrossRef] [PubMed]

50. Hüttner, E.K.; Dal Bello, F.; Arendt, E.K. Identification of lactic acid bacteria isolated from oat sourdoughs and investigation into their potential for the improvement of oat bread quality. Eur. Food Res. Technol. 2010, 230, 849-857. [CrossRef]

51. Moroni, A.V.; Dal Bello, F.; Arendt, E.K. Sourdough in gluten-free bread-making: An ancient technology to solve a novel issue? Food Microbiol. 2009, 26, 676-684. [CrossRef] [PubMed]

52. Moroni, A.V.; Arendt, E.K.; Dal Bello, F. Biodiversity of lactic acid bacteria and yeasts in spontaneously-fermented buckwheat and teff sourdoughs. Food Microbiol. 2011, 28, 497-502. [CrossRef] [PubMed]

53. Coda, R.; Rizzello, C.G.; Gobbetti, M. Use of sourdough fermentation and pseudo-cereals and leguminous flours for the making of a functional bread enriched of $\gamma$-aminobutyric acid (GABA). Int. J. Food Microbiol. 2010, 137, 236-245. [CrossRef]

54. Siragusa, S.; De Angelis, M.; Di Cagno, R.; Rizzello, C.G.; Coda, R.; Gobbetti, M. Synthesis of $\gamma$-aminobutyric acid by lactic acid bacteria isolated from a variety of Italian cheeses. Appl. Environ. Microbiol. 2007, 73, 7283-7290. [CrossRef] 
55. Rizzello, C.G.; Cassone, A.; Di Cagno, R.; Gobbetti, M. Synthesis of angiotensin I-converting enzyme (ACE)-inhibitory peptides and $\gamma$-aminobutyric acid (GABA) during sourdough fermentation by selected lactic acid bacteria. J. Agric. Food Chem. 2008, 56, 6936-6943. [CrossRef]

56. Cui, Y.; Miao, K.; Niyaphorn, S.; Qu, X. Production of gamma-aminobutyric acid from lactic acid bacteria: A systematic review. Int. J. Mol. Sci. 2020, 21, 995. [CrossRef]

57. Pandey, A.; Szakacs, G.; Soccol, C.R.; Rodriguez-Leon, J.A.; Soccol, V.T. Production, purification and properties of microbial phytases. Bioresour. Technol. 2001, 77, 203-214. [CrossRef]

58. Corsetti, A.; Settanni, L. Lactobacilli in sourdough fermentation. Food Res. Int. 2007, 40, 539-558. [CrossRef]

59. De Angelis, M.; Gallo, G.; Corbo, M.R.; McSweeney, P.L.H.; Faccia, M.; Giovine, M.; Gobbetti, M. Phytase activity in sourdough lactic acid bacteria: Purification and characterization of a phytase from Lactobacillus sanfranciscensis CB1. Int. J. Food Microbiol. 2003, 87, 259-270. [CrossRef]

60. Zotta, T.; Ricciardi, A.; Parente, E. Enzymatic activities of lactic acid bacteria isolated from Cornetto di Matera sourdoughs. Int. J. Food Microbiol. 2007, 115, 165-172. [CrossRef] [PubMed]

61. Palla, M.; Blandino, M.; Grassi, A.; Giordano, D.; Sgherri, C.; Quartacci, M.F.; Reyneri, A.; Agnolucci, M.; Giovannetti, M. Characterization and selection of functional yeast strains during sourdough fermentation of different cereal wholegrain flours. Sci. Rep. 2020, 10, 1-15. [CrossRef]

62. Milanović, V.; Osimani, A.; Garofalo, C.; Belleggia, L.; Maoloni, A.; Cardinali, F.; Mozzon, M.; Foligni, R.; Aquilanti, L.; Clementi, F. Selection of cereal-sourced lactic acid bacteria as candidate starters for the baking industry. PLoS ONE 2020, 15, e0236190.

63. Robert, H.; Gabriel, V.; Lefebvre, D.; Rabier, P.; Vayssier, Y.; Fontagné-Faucher, C. Study of the behaviour of Lactobacillus plantarum and Leuconostoc starters during a complete wheat sourdough breadmaking process. LWT Food Sci. Technol. 2006, 39, 256-265. [CrossRef]

64. Rosenquist, H.; Hansen, $\AA$. The antimicrobial effect of organic acids, sourdough and nisin against Bacillus subtilis and B. licheniformis isolated from wheat bread. J. Appl. Microbiol. 1998, 85, 621-631. [CrossRef]

65. Katina, K.; Arendt, E.; Liukkonen, K.H.; Autio, K.; Flander, L.; Poutanen, K. Potential of sourdough for healthier cereal products. Trends Food Sci. Technol. 2005, 16, 104-112. [CrossRef]

66. Poutanen, K.; Flander, L.; Katina, K. Sourdough and cereal fermentation in a nutritional perspective. Food Microbiol. 2009, 26, 693-699. [CrossRef]

67. Östman, E.M.; Nilsson, M.; Liljeberg Elmståhl, H.G.M.; Molin, G.; Björck, I.M.E. On the effect of lactic acid on blood glucose and insulin responses to cereal products: Mechanistic studies in healthy subjects and in vitro. J. Cereal Sci. 2002, 36, 339-346. [CrossRef]

68. Mamlouk, D.; Gullo, M. Acetic Acid Bacteria: Physiology and Carbon Sources Oxidation. Indian J. Microbiol. 2013, 53, 377-384. [CrossRef] [PubMed]

69. La China, S.; Zanichelli, G.; De Vero, L.; Gullo, M. Oxidative fermentations and exopolysaccharides production by acetic acid bacteria: A mini review. Biotechnol. Lett. 2018, 40, 1289-1302. [CrossRef] [PubMed]

70. Vigentini, I.; Fabrizio, V.; Dellacà, F.; Rossi, S.; Azario, I.; Mondin, C.; Benaglia, M.; Foschino, R. Set-up of bacterial cellulose production from the genus Komagataeibacter and its use in a gluten-free bakery product as a case study. Front. Microbiol. 2019, 10, 1953. [CrossRef] [PubMed]

71. Zannini, E.; Waters, D.M.; Coffey, A.; Arendt, E.K. Production, properties, and industrial food application of lactic acid bacteriaderived exopolysaccharides. Appl. Microbiol. Biotechnol. 2016, 100, 1121-1135. [CrossRef]

72. La China, S.; De Vero, L.; Anguluri, K.; Brugnoli, M.; Mamlouk, D.; Gullo, M. Kombucha tea as a reservoir of cellulose producing bacteria: Assessing diversity among Komagataeibacter isolates. Appl. Sci. 2021, 11, 1595. [CrossRef]

73. Arena, M.P.; Russo, P.; Spano, G.; Capozzi, V. From Microbial Ecology to Innovative Applications in Food Quality Improvements: The Case of Sourdough as a Model Matrix. J 2020, 3, 9-19. [CrossRef]

74. Kaditzky, S.; Seitter, M.; Hertel, C.; Vogel, R.F. Performance of Lactobacillus sanfranciscensis TMW 1.392 and its levansucrase deletion mutant in wheat dough and comparison of their impact on bread quality. Eur. Food Res. Technol. 2008, 227, 433-442. [CrossRef]

75. Falasconi, I.; Fontana, A.; Patrone, V.; Rebecchi, A.; Garrido, G.D.; Principato, L.; Callegari, M.L.; Spigno, G.; Morelli, L. Genomeassisted characterization of Lactobacillus fermentum, Weissella cibaria, and Weissella confusa strains isolated from sorghum as starters for sourdough fermentation. Microorganisms 2020, 8, 1388. [CrossRef] [PubMed]

76. Galle, S.; Schwab, C.; Arendt, E.; Gänzle, M.G. Exopolysaccharide-forming Weissella strains as starter cultures for sorghum and wheat sourdoughs. J. Agric. Food Chem. 2010, 58, 5834-5841. [CrossRef]

77. Franco, W.; Pérez-Díaz, I.M.; Connelly, L.; Diaz, J.T. Isolation of exopolysaccharide-producing yeast and lactic acid bacteria from quinoa (Chenopodium quinoa) sourdough fermentation. Foods 2020, 9, 337. [CrossRef] [PubMed]

78. Lynch, K.M.; Coffey, A.; Arendt, E.K. Exopolysaccharide producing lactic acid bacteria: Their techno-functional role and potential application in gluten-free bread products. Food Res. Int. 2018, 110, 52-61. [CrossRef] [PubMed]

79. Mattila, P.; Pihlava, J.M.; Hellström, J. Contents of phenolic acids, alkyl- and alkenylresorcinols, and avenanthramides in commercial grain products. J. Agric. Food Chem. 2005, 53, 8290-8295. [CrossRef] [PubMed]

80. Filannino, P.; Di Cagno, R.; Gobbetti, M. Metabolic and functional paths of lactic acid bacteria in plant foods: Get out of the labyrinth. Curr. Opin. Biotechnol. 2018, 49, 64-72. [CrossRef] 
81. Fernández-Peláez, J.; Paesani, C.; Gómez, M. Sourdough Technology as a Tool for the Development of Healthier Grain-Based Products: An Update. Agronomy 2020, 10, 1962. [CrossRef]

82. Katina, K.; Laitila, A.; Juvonen, R.; Liukkonen, K.H.; Kariluoto, S.; Piironen, V.; Landberg, R.; Åman, P.; Poutanen, K. Bran fermentation as a means to enhance technological properties and bioactivity of rye. Food Microbiol. 2007, 24, 175-186. [CrossRef]

83. Kariluoto, S.; Aittamaa, M.; Korhola, M.; Salovaara, H.; Vahteristo, L.; Piironen, V. Effects of yeasts and bacteria on the levels of folates in rye sourdoughs. Int. J. Food Microbiol. 2006, 106, 137-143. [CrossRef]

84. Coda, R.; Cassone, A.; Rizzello, C.G.; Nionelli, L.; Cardinali, G.; Gobbetti, M. Antifungal Activity of Wickerhamomyces anomalus and Lactobacillus plantarum during Sourdough Fermentation: Identification of Novel Compounds and Long-Term Effect during Storage of Wheat Bread. Appl. Environ. Microbiol. 2011, 77, 3484-3492. [CrossRef]

85. Rizzello, C.G.; Nionelli, L.; Coda, R.; Gobbetti, M. Synthesis of the cancer preventive peptide lunasin by lactic acid bacteria during sourdough fermentation. Nutr. Cancer 2012, 64, 111-120. [CrossRef]

86. Sadiq, F.A.; Yan, B.; Tian, F.; Zhao, J.; Zhang, H.; Chen, W. Lactic Acid Bacteria as Antifungal and Anti-Mycotoxigenic Agents: A Comprehensive Review. Compr. Rev. Food Sci. Food Saf. 2019, 18, 1403-1436. [CrossRef] [PubMed]

87. Cortés-Zavaleta, O.; López-Malo, A.; Hernández-Mendoza, A.; García, H.S. Antifungal activity of lactobacilli and its relationship with 3-phenyllactic acid production. Int. J. Food Microbiol. 2014, 173, 30-35. [CrossRef] [PubMed]

88. Ndagano, D.; Lamoureux, T.; Dortu, C.; Vandermoten, S.; Thonart, P. Antifungal activity of 2 lactic acid bacteria of the Weissella genus isolated from food. J. Food Sci. 2011, 76, M305-M311. [CrossRef] [PubMed]

89. Dalié, D.K.D.; Deschamps, A.M.; Richard-Forget, F. Lactic acid bacteria-Potential for control of mould growth and mycotoxins: A review. Food Control 2010, 21, 370-380. [CrossRef]

90. Axel, C.; Brosnan, B.; Zannini, E.; Peyer, L.C.; Furey, A.; Coffey, A.; Arendt, E.K. Antifungal activities of three different Lactobacillus species and their production of antifungal carboxylic acids in wheat sourdough. Appl. Microbiol. Biotechnol. 2016, 100, 1701-1711. [CrossRef] [PubMed]

91. Corsetti, A.; Gobbetti, M.; Rossi, J.; Damiani, P. Antimould activity of sourdough lactic acid bacteria: Identification of a mixture of organic acids produced by Lactobacillus sanfrancisco CB1. Appl. Microbiol. Biotechnol. 1998, 50, 253-256. [CrossRef] [PubMed]

92. Lavermicocca, P.; Valerio, F.; Evidente, A.; Lazzaroni, S.; Corsetti, A.; Gobbetti, M. Purification and characterization of novel antifungal compounds from the sourdough Lactobacillus plantarum strain 21B. Appl. Environ. Microbiol. 2000, 66, 4084-4090. [CrossRef]

93. Gerez, C.L.; Torino, M.I.; Obregozo, M.D.; De Font Valdez, G. A ready-to-use antifungal starter culture improves the shelf life of packaged bread. J. Food Prot. 2010, 73, 758-762. [CrossRef]

94. Zhang, C.; Brandt, M.J.; Schwab, C.; Gänzle, M.G. Propionic acid production by cofermentation of Lactobacillus buchneri and Lactobacillus diolivorans in sourdough. Food Microbiol. 2010, 27, 390-395. [CrossRef]

95. Garofalo, C.; Zannini, E.; Aquilanti, L.; Silvestri, G.; Fierro, O.; Picariello, G.; Clementi, F. Selection of sourdough lactobacilli with antifungal activity for use as biopreservatives in bakery products. J. Agric. Food Chem. 2012, 60, 7719-7728. [CrossRef]

96. Ryan, L.A.M.; Zannini, E.; Dal Bello, F.; Pawlowska, A.; Koehler, P.; Arendt, E.K. Lactobacillus amylovorus DSM 19280 as a novel food-grade antifungal agent for bakery products. Int. J. Food Microbiol. 2011, 146, 276-283. [CrossRef]

97. Axel, C.; Röcker, B.; Brosnan, B.; Zannini, E.; Furey, A.; Coffey, A.; Arendt, E.K. Application of Lactobacillus amylovorus DSM19280 in gluten-free sourdough bread to improve the microbial shelf life. Food Microbiol. 2015, 47, 36-44. [CrossRef]

98. Hassan, Y.I.; Bullerman, L.B. Antifungal activity of Lactobacillus paracasei subsp. tolerans against Fusarium proliferatum and Fusarium graminearum in a liquid culture setting. J. Food Prot. 2008, 71, 2213-2216.

99. Hassan, Y.I.; Zhou, T.; Bullerman, L.B. Sourdough lactic acid bacteria as antifungal and mycotoxin-controlling agents. Food Sci. Technol. Int. 2016, 22, 79-90. [CrossRef]

100. Angioloni, A.; Romani, S.; Pinnavaia, G.G.; Dalla Rosa, M. Characteristics of bread making doughs: Influence of sourdough fermentation on the fundamental rheological properties. Eur. Food Res. Technol. 2006, 222, 54-57. [CrossRef]

101. Corsetti, A.; Gobbetti, M.; De Marco, B.; Balestrieri, F.; Paoletti, F.; Russi, L.; Rossi, J. Combined effect of sourdough lactic acid bacteria and additives on bread firmness and staling. J. Agric. Food Chem. 2000, 48, 3044-3051. [CrossRef] [PubMed]

102. Gobbetti, M.; Corsetti, A.; Rossi, J. Interaction between lactic acid bacteria and yeasts in sour-dough using a rheofermentometer. World J. Microbiol. Biotechnol. 1995, 11, 625-630. [CrossRef] [PubMed]

103. Clarke, C.I.; Schober, T.J.; Arendt, E.K. Effect of single strain and traditional mixed strain starter cultures on rheological properties of wheat dough and on bread quality. Cereal Chem. 2002, 79, 640-647. [CrossRef]

104. Cappa, C.; Lucisano, M.; Raineri, A.; Fongaro, L.; Foschino, R.; Mariotti, M. Gluten-Free Bread: Influence of Sourdough and Compressed Yeast on Proofing and Baking Properties. Foods 2016, 5, 69. [CrossRef] [PubMed]

105. Picozzi, C.; Mariotti, M.; Cappa, C.; Tedesco, B.; Vigentini, I.; Foschino, R.; Lucisano, M. Development of a Type I gluten-free sourdough. Lett. Appl. Microbiol. 2016, 62, 119-125. [CrossRef]

106. Melini, V.; Melini, F. Strategies to extend bread and GF bread shelf-life: From Sourdough to antimicrobial active packaging and nanotechnology. Fermentation 2018, 4, 5-10.

107. Lavermicocca, P.; Valerio, F.; De Bellis, P.; Sisto, A. Leguérinel, Sporeforming bacteria associated with bread production: Spoilage and toxigenic potential. In Food Hygiene and Toxicology in Ready-to-Eat Foods; Kotzekidou, P., Ed.; Academic Press: San Diego, CA, USA, 2016; pp. 275-293. 
108. Capozzi, V.; Fragasso, M.; Romaniello, R.; Berbegal, C.; Russo, P.; Spano, G. Spontaneous Food Fermentations and Potential Risks for Human Health. Fermentation 2017, 3, 49. [CrossRef]

109. Gobbetti, M.; De Angelis, M.; Corsetti, A.; Di Cagno, R. Biochemistry and physiology of sourdough lactic acid bacteria. Trends Food Sci. Technol. 2005, 16, 57-69. [CrossRef]

110. Luti, S.; Galli, V.; Venturi, M.; Granchi, L.; Paoli, P.; Pazzagli, L. Bioactive Properties of Breads Made with Sourdough of Hull-Less Barley or Conventional and Pigmented Wheat Flours. Appl. Sci. 2021, 11, 3291. [CrossRef]

111. Marcotrigiano, V.; Lanzilotti, C.; Rondinone, D.; De Giglio, O.; Caggiano, G.; Diella, G.; Orsi, G.B.; Montagna, M.T.; Napoli, C. Food labelling: Regulations and Public Health implications. Ann. Ig 2018, 30, 220-228. 